\title{
Consumer attitudes towards luxury fashion apparel made in sweatshops
}

\section{BACKGROUND}

The fashion apparel industry has been aggressively embroiled in the controversial use of sweatshops (Coakley and Kates 2013; Palmer 2013). Most American apparel manufacturers and retailers source and import their products from approximately 150 undeveloped countries where sweatshops are commonly found (Harrison and Scorse 2010). This accentuates the already fierce debate on this issue among the media, student groups, union leaders, government officials and even environmentalists (Harrison and Scorse 2010; Powell and Zwolinski 2012). Brands such as H\&M, Nike, Ralph Lauren, DKNY, Adidas, amongst many other familiar brand names were found to be utilising sweatshops to manufacture their apparel (Snyder 2010; Palmer 2013). Consumers are concerned not only of the products that a retailer sells or what the best prices they can offer, but also the conditions of how the products are being produced (Snyder 2010; Palmer 2013; Powell and Zwolinski 2012).

The recent tragic collapse of a garment factory in Bangladesh sparked and renewed media attention on luxury brands who have had a fair share in using sweatshops to manufacture their expensive goods, which further questions not only the poor working conditions for sweatshop workers, but also the consumption of ethical products in the luxury context (Palmer 2013; Powell and Zwolinski 2012; Snyder 2010). Davies, Lee and Ahonkhai (2012) cited that while research in sweatshops is rampant in other contexts, no studies to date have specifically looked at luxury fashion products. As highlighted by many researchers (e.g. Barber et al., 2012; Shen et al., 2012; Sweetin et al., 2013), the question arises if the ethical stance of the consumers may lead to the willingness to pay more for luxury fashion apparel that are not made in sweatshops.

Similarly, in the context of the purchase of luxury fashion apparels made in sweatshops, there is very little work done with respect to social norms. In particular, recent studies such as Fuchs et al. (2013) has highlighted that susceptibility to interpersonal influence on purchase intent may very well be highly influential to boycotting products made in sweatshops (Khare 2011). Integrity is also perceived to be related to social norms and can be a significant negative influence on purchase intent (Hamelin, Nwankwo and Hadouchi 2012). Mukhopadhyay and Johar (2005) have found that self-efficacy may have a significant effect 
on purchase intention. In the context of sweatshops, Kang, Liu and Kim (2013) cited that there is still a need to investigate if this could be a potential influence on purchase intent as well as the willingness to pay more for luxury fashion apparel not made in a sweatshop.

Building on the gaps above, this paper strives to respond to the call for research (such as, Hung et al., 2011) to better understand consumer purchase intentions towards luxury fashion apparels made in sweatshops. The theory of planned behaviour (TPB) underpins the model to test the relationships between attitudes, social norms, and perceived behavioural control on consumer intention to purchase luxury fashion apparel made in sweatshops. It further examines the relationship between intention and the willingness to purchase luxury fashion apparels not made in sweatshops.

The organisation of this paper will begin with a discussion on extant literature and leading to the model and hypotheses development. This is followed by a description of the research method. The research method will then lead to the discussion of the findings and analysis. Finally, the study will conclude with managerial implications and limitations arising from this research.

\section{RELEVANT LITERATURE AND HYPOTHESES DEVELOPMENT}

\section{Theory of Planned Behaviour (TPB)}

Extant literature has shown evidence that the theory of planned behaviour model (Ajzen 1991) is widely used by market researchers to investigate consumers' purchase intention towards a particular product or service. Based on the outcome of behaviour and attitude (Horng, Su and So 2013), the framework is largely adopted by researchers today to evaluate the decision making of individuals, for instance, what triggers a person to behave in a certain way (Southey 2011). Such adoption would allow researchers to better understand consumers' buying behaviour, hence, be able to offer what the market wants (Horng, Su and So 2013). In this study, the theory of planned behaviour will be used as a framework to examine consumers' attitudes towards luxury fashion apparel made in sweatshops, social norms which describe the social pressure a person receives while performing certain behaviour, perceived behavioural control which implies a person's perception towards the ability of performing the behaviour and how they influence the intention to purchase luxury fashion apparel made in 
sweatshops and the willingness to pay more for luxury fashion apparel not made in sweatshops (Fuchs et al., 2013; Pickett et al., 2012).

\section{Attitudes towards apparel made in sweatshops}

A sweatshop is often referred to as poor factory working conditions where workers are exploited to long working hours with low wages, child-labour and abusive treatment at work (Shaw et al. 2007; Shen et al., 2012). Research stated that these issues are more likely to happen in countries that are less developed where labour laws and workers' rights are less strict (Fuchs et al., 2013; Shaw et al., 2007). Due to such a phenomenon, consumers today are more aware of the severity of sweatshop issues on health, safety and human rights. A growing number of consumers have also tried to boycott sweatshop products (Ballinger 2011).

Research (e.g. Shaw and Tomolillo 2004; Smith 2005) has shown that awareness campaigns is said to be an important factor influencing consumers' attitudes towards human rights issues. Due to the advancement of these systems, consumers today are more knowledgeable and educated about the rising concerns of environmental and social issues that have changed the modern consumption culture (Harrison and Scorse 2010; Judith 2011). In addition, the increasing involvement of consumer activist groups, media and availability of ethical products are some of the determinants that are changing consumers' consumption and purchasing behaviour (Carrington, Neville and Whitwell 2010; Synder 2012). Considering giant clothing companies such as Nike, Gap Inc and Levi Strauss \& Co who have been largely exploiting sweatshops, there is still a limited amount of research being done in the luxury fashion apparel context. Although ethical issues are often not being examined within the luxury goods context, there are researchers who think it is important to understand ethics from the luxury goods perspective (Garcia-Johnson and Sasser 2001; Hilton, Ghong Ju and Stephen 2004). Considering the environmental issues today, creating a sustainable society has always been widely discussed (Finn 2011). However, in reality, people tend to prefer living in their comfort zone rather than taking real actions. More so, market researchers have found that doubt is the key to what is believed to be holding some consumers back from responding to ethical conduct (Hustvedt and Bernard 2010; Li-Wen 2010).

Although many corporations today have claimed themselves to be acting in socially responsible ways, doubts still arise within consumers when it comes to purchase intention of a product as there is still limited information being released to the public regarding how, 
when or for whom CSR works are conducted for (Auger et al., 2003; Eabrasu 2012). As such, it can be postulated that:

$\boldsymbol{H}_{\text {1a: }}$ Attitudes toward social consequences will have a positive relationship towards the intention to purchase luxury fashion apparel made in sweatshops.

$\boldsymbol{H}_{1 \boldsymbol{b}}$ : Attitudes toward social consequences will have a negative relationship towards the willingness to pay more for luxury fashion apparel not made in sweatshops.

$\boldsymbol{H}_{2 a}$ : Attitudes toward apparel made in sweatshops will have a positive relationship towards the intention to purchase luxury fashion apparel made in sweatshops.

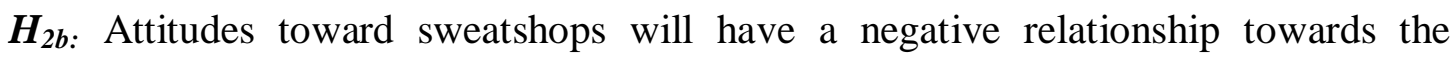
willingness to pay more for luxury fashion apparel not made in sweatshops.

$\boldsymbol{H}_{3 a}$ : Attitudes toward purchasing behaviour of products made in sweatshops will have a negative relationship towards the intention to purchase luxury fashion apparel made in sweatshops.

$\boldsymbol{H}_{3 b}$ : Attitudes toward purchasing behaviour of products made in sweatshops will have a negative relationship towards the willingness to pay more for luxury fashion apparel not made in sweatshops.

\section{Social Norms (Susceptibility to interpersonal influence; Integrity; Status consumption)}

Social norm is the influence of social pressure an individual receives on how important opinions of others are to them when making decisions (Horng, Su and So 2013). They are exemplified as the beliefs and value a person draw from the perceptions they get from different people or social groups (Aranzadi 2011; Pickett et al., 2012; Vitell, Keith and Mathur 2011). Consumer's susceptibility to interpersonal influence is often discussed interchangeably with social influence. Bearden, Netemeyer, and Teel $(1989,473)$ stated that a person's susceptibility is often influenced by the characteristics or personalities of others. In this paper, four social norms are considered.

Susceptibility to interpersonal influence comprising of two dimensions is well researched in the literature. Informational susceptibility is the tendency to perceive or to obtain information from others, meaning that individuals tend to be more susceptible to information if they often seek advice from others or observe how they behave (Bearden, Netemeyer and Teel 1989; Clark and Goldsmith 2006; Spector 1983). Research also highlights that a person may seem to be more susceptible to information when he or she actively seeks information from others 
that he or she perceives to be knowledgeable about the product (d'Rozario 2012; Jih-Hsin and Cheng-Kiang 2005). As such their opinions is essential as it helps consumers to make better decisions by setting a point of reference when consumers have little knowledge about the product (Dodd et al., 1998; Gupta 2011; Shukla 2012). Normative susceptibility refers to the tendency to conform to the expectations of others and is often concerned about how they would impress others (Bearden, Netemeyer and Teel 1989; Clark and Goldsmith 2006; Spector 1983). Early literature defines value-expressive influence as an individual's desire to enhance self-image by association with a reference group. Such influence takes place when a person is motivated by his or her desire to fit into a particular group. In order to reflect selfidentification in the associated group, one may tend to observe how other people behave (Gupta 2011). For instance, a person may subconsciously follow what others do by observing their behaviour because he or she believes that is what reflects the reality (e.g. a person may purchase a certain clothing brand that his or her friends believe to be an expensive brand without even knowing the actual product). Hence what others believe to be true tend to have an influence on the person (Hermans, Schaefer and Haytko 2007; Jih-Hsin and Cheng-Kiang 2005). Recent studies regarding the media today indicates that due to the increase usage of social networks, such prevalence have become a powerful tool to many clothing manufacturers. Most of the clothing companies today are increasingly using social networks as a platform for commercial purposes as it is the easiest and quickest way to reach out to potential consumers (Wolny and Claudia 2013). Majority of the people tend to signify fashion as how individuals portray themselves in a society. In order to show their belonging to a certain society, they tend to take possessions in the values, qualities, cultures, and interests of the society.

Based on earlier discussion, a person is more susceptible to normative influence when he or she tries to gain acceptance from others by possessing their behaviours. As a result, individuals believe that responding to such possessions would then provide them with the affirmation of their identity (Khare 2011). As such, it can be postulated that:

$\boldsymbol{H}_{4 a}$ : Informational susceptibility to interpersonal influence will have a negative relationship towards the intention to purchase luxury fashion apparel made in sweatshops. 
$\boldsymbol{H}_{4 b}$ : Informational susceptibility to interpersonal influence will have a negative relationship towards the willingness to pay more for luxury fashion apparel not made in sweatshops.

$\boldsymbol{H}_{5 a}$ : Normative susceptibility to interpersonal influence will have a positive relationship towards the intention to purchase luxury fashion apparel made in sweatshops.

$\boldsymbol{H}_{5 b}$ : Normative susceptibility to interpersonal influence will have a positive relationship towards the willingness to pay more for luxury fashion apparel not made in sweatshops.

Integrity is defined as the tendency of being honest or the state of having strong moral values (Nguyen, Melewar and Chen 2013). Researchers found that what is believed to be influencing consumers' purchase intention is often affected by their level of integrity towards the particular product (Laeequddin and Sardana 2010). It is believed that people who have high integrity are more likely to respond to ethical conduct by making ethical purchase decisions as compared to people who have low integrity (Floyd et al., 2013; Lewick and Bunker 1996). On the other hand, market researchers also believe that trust is sometimes the predominant influencer of what builds a person's integrity as people tend to react more proactively when they have trust in a particular thing or person (Lu, Zhao and Wang 2010). Trust develops when one puts himself in an uncertain situation expecting a favourable return (e.g. consumers' integrity towards a product increases when they believe that buying the product will in turn benefit them) (Kline 2012; Rotter 1967). As a result, when trust develops, it increases a person's integrity towards the product which will ultimately lead them to purchase intention. Therefore, consumers who have high level of awareness about the issues of sweatshops will be less likely to purchase luxury fashion apparel made in sweatshops. In fact, the level of integrity would ultimately influence them to be willing to pay more for luxury fashion apparel that is not made in sweatshops (Hamelin, Nwankwo and Hadouchi 2012). It can be postulated that:

$\boldsymbol{H}_{6 \boldsymbol{a}}$ : Integrity will have a negative relationship towards the intention to purchase luxury fashion apparel made in sweatshops.

$\boldsymbol{H}_{6 b}$ : Integrity will have a positive relationship towards the willingness to pay more for luxury fashion apparel not made in sweatshops. 
Luxury goods are often consumed to show one's wellbeing and self-pleasure such as statusseeking (Fuchs et al., 2013). Apart from seeking uniqueness and quality, luxury goods experts argued that luxury-seeking consumers are also seeking conspicuousness and hedonism (Finn 2011). Davies, Lee and Ahonkhai (2012) stated that, since the consumption of luxury goods is to increase one's hedonism. Thus, taking ethical aspect into consideration when purchasing luxury goods is essential (e.g. ethical concern such as whether to purchase luxury fashion apparel made in sweatshops). Upon further elaboration, consumers who can afford luxury goods should pay even more attention to ethics as the key motivation behind luxury consumption is to present one's high-living standards (Husic and Cicic 2008). Value is the key to the argument, whereby consumers will only purchase something that will in turn benefit them (e.g. a person would purchase a certain clothing brand just to show his or her social status to others) (Haderspeck 2013; Liao and Hsieh 2013). Lastly, brand familiarity is said to have an influence on consumers' integrity towards purchasing behaviour; consumers with low level of awareness about a product are less likely to purchase the product than those who have a higher level of awareness because of the uncertainty of the value the product will offer (Nica 2013). As a result, status consumers are more conscious about their achievements, hence, showing their accomplishment to others is important. Therefore, consumers who often seek status will most likely purchase luxury fashion apparel regardless of whether they are made in sweatshops. Thus, it can be postulated that:

$\boldsymbol{H}_{7 a}$ : Status consumption will have a positive relationship towards the intention to purchase luxury fashion apparel made in sweatshops.

$\boldsymbol{H}_{7 b}$ : Status consumption will have a positive relationship towards the willingness to pay more for luxury fashion apparel not made in sweatshops.

\section{Perceived Behavioural control}

Self-efficacy is a person's self-belief in his own ability to perform a task. Self-efficacy often has a direct relation to perceived behavioral control which may affect a person's attitudes or behavior (Ajzen 1991; Man 1998). In other words, a person's self-efficacy towards performing a task is determined by how well he can have control over the behavior towards the completion of the task. Every task performed has its success and failure and self-efficacy takes place to examine if one is actually capable of performing the task (e.g. a social smoker would easily say that he is not addicted to smoking or it is easy for him to quit smoking 
because he is not addicted to smoking) (Fukukawa and Ennew 2010; McKee, Simmers and Licata 2006). It can be argued that consumers who have high self-efficacy would truly believe that they could make a change to minimize the issue of sweatshops through boycotting luxury fashion apparel that are made in sweatshops. In doing so, they are supporting sweatshop free luxury fashion brands. It can be postulated that:

$\boldsymbol{H}_{8 a}$ : Self-efficacy will have positive relationship towards the intention to purchase luxury fashion apparel made in sweatshops.

$\boldsymbol{H}_{8 b}$ : Self-efficacy will have positive relationship towards the willingness to pay more for luxury fashion apparel not made in sweatshops.

\section{Purchase intention to willingness to pay}

In order to better measure consumers' willingness to pay, it is argued that the more consumers understand about the ethical dimensions of the product, the more likely they are to purchase the product. Therefore, the higher the degree of favourableness on purchase intention would increase their willingness to pay a higher price (Barber et al., 2012; Shen et al., 2012). Due to the increasing concerns surrounding issues about environmentalism such as the issue of sweatshops, consumers are becoming more conscious about the products they buy (Barber 2012, Dean, Raats and Shepherd 2012; Sweetin et al., 2013). This means that, they tend to respond to these concerns by purchasing products that would minimise environmental issues (Sweetin et al., 2013). Similar studies were also tested in the wine industry. It was found that average wine consumers were willing to pay more for organic wine. However, uncertainty still exist within the premium wine consumers as they claimed that they will not pay more for environmentally friendly wine if there is an issue with quality (Barber 2012; Lin et al., 2011). Self-identity refers to how individuals represent themselves in different social settings (e.g. a person would think of himself as someone who concern about the environment if he is surrounded by peers who are green consumers) (Dean, Raats and Shepherd 2012). Consumers' purchase intentions are the signal of actual purchasing. Therefore, it is important to take into consideration how purchase intention affects actual buying behaviour, thus, the importance of understanding consumers' perception towards a product. On the other hand, willingness to pay for a product takes place when there is assurance about what the product can offer, hence, paying a price for the product shows the value of the product. In addition to that, willingness to pay more occurs when the value of the 
product exceeds the consumers' perceived value towards the product (Dean, Raats and Shepherd 2012; Keh and Xie 2009). It can be postulated that:

$\boldsymbol{H}_{9}$ Intention to purchase luxury fashion apparel made in sweatshops will have a negative impact towards the willingness to pay more for luxury fashion apparel not made in sweatshops.

\section{～Insert Fig. 1 Here}

\section{METHODOLOGY}

\section{Data Collection}

Data was collected via a mall intercept at a major shopping complex in a major city in Australia. Shoppers were approached to participate in a self-administered questionnaire by trained interviewers. Every fifth individual that crossed a designated spot outside the main entrance of the mall was approached to participate. Prior to the data collection, interviewers were given instructions on how to administrate the survey instrument and to ensure demographic profiles of respondents are included. Data collection was conducted over a three-week period including both weekdays and weekend. Measuring consumer's attitudes and perceptions towards apparel made in sweatshops in a mall or shopping related environment would allow population of interest to relate to what the research intends to investigate (Wang et al., 2005; Sweetin et al., 2013).

\section{Survey Instrument}

The survey instrument was developed into five sections consisted of established scales and a section on demographics. The description of scale items and their reliabilities are reflected in Table 1. Sections A and B measured consumer's susceptibility towards interpersonal influence, integrity and status consumption. The next section shows a stimulus which is a montage of pictures and information about the recent collapse of the factory in Bangladesh. Section $\mathrm{C}$ measured the attitudes and purchase intentions towards luxury fashion apparel made in sweatshops. Section D measured consumer's self-efficacy towards luxury fashion apparel made in sweatshops. Section E measured consumer's intention towards purchasing behaviour of apparel made in sweatshops. All items were measured on a seven point Likert scale with 1 representing "strongly disagree" and 7 "strongly agree".

\section{Insert Table 1 here}




\section{FINDINGS AND DISCUSSION}

\section{Samples}

260 questionnaires were collected and of these, 63 responses were discarded due to incompletion. The remaining 197 usable responses were then gathered and analysed with SPSS software version 21. The sample distribution is shown in Table 2. $48.2 \%$ of the respondents were male, and $51.8 \%$ were females. Majority of the respondents were between 21-35 years old (47.7\%) earning below $\$ 15,000$ (58.9\%) and have either a diploma or certificate $(42.6 \%)$.

\section{Insert Table 2 here}

\section{Attitudes towards luxury fashion apparel made in sweatshops}

An exploratory factor analysis was conducted on the original 12-item attitudes towards intention to purchase luxury fashion apparel made in sweatshops scale. Through varimax rotation, three factors emerged namely "Attitudes towards social consequences", "Attitudes towards sweatshops" and "Attitudes towards purchasing behaviour". In total, they were reduced to 10 items with an acceptable range of reliabilities as reflected in Table 3. The scale of attitudes towards intention to purchase luxury fashion apparel made in sweatshops is clearly three-dimensional as postulated through recent literature. As such, these three factors were used independently for all subsequent regression analysis as depicted in the model.

\section{Insert Table 3 here}

Influence of antecedents on "Intention to purchase luxury fashion apparel made in sweatshops"

Multiple linear regressions were conducted between the three sets of antecedents and the "intention to purchase luxury fashion apparel made in sweatshops" Based on the results in Table 4, both attitudes towards social consequences ( $\mathrm{p}<0.000, \beta=0.347$, adjusted $\mathrm{R}^{2}=0.286$ ) and attitudes towards purchasing behaviour of product made in sweatshops $(p<0.000, \beta=$ 0.331 , adjusted $R^{2}=0.286$ ) showed a significant relationship towards intention to purchase luxury fashion apparel made in sweatshops. However, attitudes towards sweatshops was 
found to be insignificant $\left(\mathrm{p}<0.911, \beta=-0.007\right.$, adjusted $\left.\mathrm{R}^{2}=0.286\right)$. Hence $\mathrm{H}_{2 a}$ and $\mathrm{H}_{3 a}$ are supported and $H_{1 a}$ is rejected.

For social norms, only integrity is found to be significant $\left(\mathrm{p}<0.000, \beta=0.285\right.$, adjusted $\mathrm{R}^{2}=$ 0.111). Therefore, $H_{6 a}, H_{4 a}, H_{5 a}$ and $H_{7 a}$ are rejected.

Finally for perceived behavioural control (PBC), self-efficacy showed a significant positive relationship with "purchase intention towards luxury fashion apparel made in sweatshops" ( $\mathrm{p}<0.000, \beta=0.339$, adjusted $\left.\mathrm{R}^{2}=0.110\right)$, hence, $H_{8 a}$ is supported.

\section{～Insert Table 4 here}

\section{Influence of antecedents on "Willingness to pay more for luxury branded apparel not made in sweatshops"}

Multiple linear regressions were conducted between the three sets of antecedents and the "willingness to pay more for luxury fashion apparel made in sweatshops". Based on the results in Table 5, attitudes towards social consequences $\left(\mathrm{p}<0.000, \beta=0.292\right.$, adjusted $\mathrm{R}^{2}=$ $0.161)$ and attitudes towards purchasing behaviour of product made in sweatshops $(\mathrm{p}<0.003$, $\beta=0.213$, adjusted $R^{2}=0.161$ ) showed a significant relationship towards willingness to pay more for luxury fashion apparel made in sweatshops. However, attitudes towards sweatshops was found to be insignificant ( $\mathrm{p}<0.818, \beta=0.016$, adjusted $\mathrm{R}^{2}=0.161$ ). Hence $H_{1 b}$ and $H_{3 b}$ are supported and $H_{2 b}$ is rejected.

For social norms, only integrity showed a significant relationship $(\mathrm{p}<0.000, \beta=0.284$, adjusted $R^{2}=0.059$ ) towards willingness to pay more for luxury fashion apparel not made in sweatshops. $\mathrm{H}_{4 b}, \mathrm{H}_{5 b}$ and $\mathrm{H}_{7 b}$ are rejected and $\mathrm{H}_{6 b}$ is supported.

Finally for perceived behavioural control (PBC), there is a positive relationship between selfefficacy and "willingness to pay more for luxury fashion apparel not made in sweatshops" ( $\mathrm{p}<0.000, \beta=0.278$, adjusted $\mathrm{R}^{2}=0.068$ ). As a result, $\mathrm{H}_{8 b}$ is supported.

\section{Influence of purchase intention on "Willingness to pay more for luxury fashion apparel not made in sweatshops"}


Linear regression was conducted between "intention to purchase luxury fashion apparel made in sweatshops" and "willingness to pay more for luxury fashion apparel made in sweatshops" to test $H_{9}$. The results revealed that, the intention to purchase luxury fashion apparel made in sweatshops was found to have a significant positive relationship $\left(\mathrm{p}<0.000, \beta=0.390, \mathrm{R}^{2}=\right.$ 0.147 ) towards willingness to pay more for luxury fashion apparel not made in sweatshops. Therefore, $H_{9}$ is supported.

\section{Insert Table 5 here}

\section{DISCUSSION AND IMPLICATIONS}

There were a number of interesting results which emerged in this study. It was found that attitudes towards social consequences have significant influence on the purchase intention towards luxury fashion apparel made in sweatshops and the willingness to pay more for luxury fashion apparel not made in sweatshops. This shows that consumers who are aware of the negative impact that sweatshops will bring about to the society will not intend to purchase luxury clothing that is made from sweatshops, but rather they would be willing to pay more for luxury clothing that is not made in sweatshops. Luxury brands should take this cue and strengthen their branding strategies by focussing on brand exclusivity (Spiggle, Nguyen and Caravella 2012). In other words, brands being able to produce luxury clothing in a humane environment with authentic material and genuine artisan skills that is far different from how sweatshop products are manufactured. Another related strategy would be for brand owners to increase its brand exclusiveness through the adoption of "super-premium" pricing. Through such adoption, products are set at a much higher price than the market price so that the skill work of the artisans who do not use sweatshops to manufacture their products can be accredited. More so, it is the means to tell the public that their products are free from sweatshops (Hudders, Pandelaere and Vyncke 2013). It can be built further as a unique selling proposition and further enhance itself by building a cult or niche market.

Attitude towards purchasing behaviour of products made in sweatshops is also shown to have an influence on the purchase intention towards luxury fashion apparel made in sweatshops and the willingness to pay more for luxury fashion apparel. Considering that consumers' perception towards sweatshops do have a direct influence on purchase intention and the willingness to pay more, luxury brand owners should work closely with brand advertisers to 
continue enhance its' brand image through different promotional campaigns. The message should appeal to the respect for quality, craftsmanship and skills that these artisans have taken years to master.

Integrity is found to influence both intention to purchase and willingness to pay more for products not made in sweatshops. From the social policy point of view, the emphasis here should be upon educating consumers about the importance of ethics and moral values with regard to sweatshops. Based on the literature, this needs to be educated and exercised at a young age. Educational programs on integrity should not be limited to just schools, but also through television programs and media. In fact, educational programs should be introduced to the general public such as consumers and domestic businesses from different industries (Paul 2008). It is important to understand that introducing educational programs will not only change consumers' purchasing behaviour but also manufacturers' purchase and selling behaviour (Paul 2008). Corporate social responsibility should be emphasized here, as it is important that luxury brand manufacturers are showing goodwill by contributing benefits to the society. There is evidence that companies that show such involvement tend to have higher corporate reputation in the public hence, able to gain competitive advantage over others (Chitakornkijsil 2012; Gatti, Caruana and Snehota 2012). As a result, when luxury brand companies are also taking ethical aspects into consideration, it will build an image in consumers' mind whereby these companies are helping to minimise social issues. Therefore, as consumers, they should also show contribution to the society by supporting these luxury products such as paying more for luxury branded products that are not made in sweatshops. In the long run, luxury brand companies should consider building an image of strong ethical values and social responsibility to win consumers over.

Results also show that consumers who have higher self-efficacy do not intend to purchase luxury fashion apparel made in sweatshops, but willing to pay more for luxury fashion apparel not made in sweatshops. To better increase consumers' level of self-efficacy, it is important to educate them about sweatshop issues and its negative impact on the society (Armitage and Connor 2001). What is actually happening in countries where sweatshops are commonly found (e.g. life story of people who are caught in sweatshops in less-developed countries; pictures of how sweatshop products are made) should be revealed to the general public through relevant social media (Paul 2008). These could be ingrained into the message appeals on the advertisements. More so, other social policy initiatives can also be 
implemented. Policy makers should work closely with the government to constrict laws on trading so that any unlawful trading within the country can be prohibited. On the other hand, penalties should also be given to businesses that are found guilty for committing unlawful trade. Through media disclosure and strict laws being implemented, unlawful business operations such as sweatshops will be better controlled (Kang, Liu and Kim 2013). From the exposure to what sweatshops are like and knowing that the government is contributing at their best to minimise social issues would ultimately increase consumers' self-efficacy to boycott luxury brands that use sweatshops to manufacture their products or to boycott buying products, consequently increase their willingness to support luxury fashion apparel that are not made in sweatshops.

\section{CONCLUDING COMMENTS}

There are a number of limitations worthy of improvement and future research. The study was conducted using mall intercept method, which may limit the populations that could be reached. Those who may purchase may not be regular shoppers at a shopping mall but may be in wholesale markets where sweatshop products are largely sold. As the study is a snapshot of consumers in Australia, extensions to populations of other countries of different socioeconomic groups which may produce different results.

There are possible extensions to this which is to focus on studying the long-term effects of sweatshops for testing at a later stage to examine if the effects have changed. Further exploration using qualitative approaches to examine consumer purchase behaviour of luxury branded products may provide deeper insights. As this study is only looking at luxury brands in general, therefore, looking at other product categories can also be considered. Further studies regarding brand loyalty can also be tested in area such as "how sweatshops influence brand loyal consumers" (e.g. will sweatshops sway away consumers' brand loyalty or have no effect on brand loyalty?). Other variables such as consumer guilt can be used as a potential moderator for the different relationships. 


\section{References}

Ajzen, Icek. "The Theory of Planned Behavior." Organizational behavior and human decision processes 50, no. 2 (1991): 179-211.

Ang, Swee Hoon, Peng Sim Cheng, Elison AC Lim, and Siok Kuan Tambyah. "Spot the Difference: Consumer Responses Towards Counterfeits." Journal of Consumer Marketing 18, no. 3 (2001): 219-35.

Aranzadi, Javier. "The Possibilities of the Acting Person within an Institutional Framework: Goods, Norms, and Virtues." Journal of Business Ethics 99, no. 1 (2011): 87-100.

Armitage, Christopher J, and Mark Conner. "Efficacy of the Theory of Planned Behaviour: A Meta - Analytic Review." British journal of social psychology 40, no. 4 (2001): 47199.

Auger, Pat, Paul Burke, Timothy M Devinney, and Jordan J Louviere. "What Will Consumers Pay for Social Product Features?". Journal of Business Ethics 42, no. 3 (2003): 281-304.

Barber, Nelson. "Consumers' Intention to Purchase Environmentally Friendly Wines: A Segmentation Approach." International Journal of Hospitality \& Tourism Administration 13, no. 1 (2012): 26-47.

Bearden, William O., Richard G. Netemeyer, and Jesse E. Teel. "Measurement of Consumer Susceptibility to Interpersonal Influence." Journal of Consumer Research 15, no. 4 (1989): 473-81.

Carrington, Michal, Benjamin Neville, and Gregory Whitwell. "Unpacking the EthicallyMinded Consumer: Understanding the Role of the 'Personal Journey' Life Project." Advances in Consumer Research - European Conference Proceedings 9 (2011): 599601.

Chitakornkijsil, Pranee. "Brand Integrity, Advertising and Marketing Ethics as Well as Social Responsibility." International Journal of Organizational Innovation 4, no. 4 (Spring2012 2012): 109-30.

Clark, Ronald A, and Ronald E Goldsmith. "Global Innovativeness and Consumer Susceptibility to Interpersonal Influence." The Journal of Marketing Theory and Practice 14, no. 4 (2006): 275-85.

Coakley, Mathew, and Michael Kates. "The Ethical and Economic Case for Sweatshop Regulation." Journal of Business Ethics 117, no. 3 (2013): 553-58.

D'Rozario, Denver, and Yang Guang. "The Effect of Susceptibility to Interpersonal Influence on the Pre-Purchase External Information-Search Tendencies of Chinese-Americans." International Journal of China Marketing 3, no. 1 (2012): 120-39.

Davies, Iain, Zoe Lee, and Ine Ahonkhai. "Do Consumers Care About Ethical-Luxury?". Journal of Business Ethics 106, no. 1 (2012): 37-51.

Dean, Moira, Monique M. Raats, and Richard Shepherd. "The Role of Self-Identity, Past Behavior, and Their Interaction in Predicting Intention to Purchase Fresh and Processed Organic Food1." Journal of Applied Social Psychology 42, no. 3 (2012): 669-88.

Dodd, Christopher A, Ian Clarke, Steve Baron, and Vicky Houston. "Practitioner Papers:'Looking the Part': Identity, Meaning and Culture in Clothing PurchasingTheoretical Considerations." Journal of Fashion Marketing and Management 4, no. 1 (2000): 41-48.

Eabrasu, Marian. "A Moral Pluralist Perspective on Corporate Social Responsibility: From Good to Controversial Practices." Journal of Business Ethics 110, no. 4 (2012): 42939. 
Eastman, Jacqueline K., Bill Fredenberger, David Campbell, and Stephen Calvert. "The Relationship between Status Consumption and Materialism: A Cross-Cultural Comparison of Chinese, Mexican, and American Students." Journal of Marketing Theory \& Practice 5, no. 1 (Winter97 1997): 52.

Emmelhainz, Margaret A., and Ronald J. Adams. "The Apparel Industry Response to "Sweatshop" Concerns: A Review and Analysis of Codes of Conduct." Journal of Supply Chain Management 35, no. 3 (Summer99 1999): 51-57.

Finn, Angela L. "Luxury Fashion: The Role of Innovation as a Key Contributing Factor in the Development of Luxury Fashion Goods and Sustainable Fashion Design." Paper presented at the Conference Proceedings 2011 Fashion \& Luxury: Between Heritage and Innovation, 2011.

Floyd, Larry A., Feng Xu, Ryan Atkins, and Cam Caldwell. "Ethical Outcomes and Business Ethics: Toward Improving Business Ethics Education." Journal of Business Ethics 117, no. 4 (2013): 753-76.

Fuchs, Christoph, Emanuela Prandelli, Martin Schreier, and Darren W. Dahl. "All That Is Users Might Not Be Gold: How Labeling Products as User Designed Backfires in the Context of Luxury Fashion Brands." Journal of Marketing 77, no. 5 (2013): 75-91.

Fukukawa, Kyoko, and Christine Ennew. "What We Believe Is Not Always What We Do: An Empirical Investigation into Ethically Questionable Behavior in Consumption." Journal of Business Ethics 91 (2010): 49-60.

Gatti, Lucia, Albert Caruana, and Ivan Snehota. "The Role of Corporate Social Responsibility, Perceived Quality and Corporate Reputation on Purchase Intention: Implications for Brand Management." Journal of Brand Management 20, no. 1 (2012): 65-76.

Gereffi, Gary, Ronie Garcia-Johnson, and Erika Sasser. "He N-Indus." Foreign Policy, no. 125 (2001): 56-65.

Gupta, Nitin. "Extent of Susceptibility to Interpersonal Influence and Price Sensitivity among Indian Youth: Is There a Relationship between These Two Constructs?". Young Consumers 12, no. 4 (2011): 361-69.

Haderspeck, Jennifer. "Upholding Product Quality and Brand Integrity." Beverage Industry 104, no. 7 (2013): 51-52.

Hamelin, Nicolas, Sonny Nwankwo, and Rachad El Hadouchi. "'Faking Brands': Consumer Responses to Counterfeiting." Journal of Consumer Behaviour 12, no. 3 (2013): 15970.

Harrison, Ann, and Jason Scorse. "Multinationals and Anti-Sweatshop Activism." The American Economic Review (2010): 247-73.

Hermans, Charles M., Allen D. Schaefer, and Diana Haytko. "A Cross-National Examination of the Dimensionality of the Consumer Susceptibility to Interpersonal Influence Scale." International Journal of Business Research 7, no. 5 (2007): 186-91.

Hilton, Brian, Choi Ghong Ju, and Chen Stephen. "The Ethics of Counterfeiting in the Fashion Industry: Quality, Credence and Profit Issues." Journal of Business Ethics 55, no. 4 (2004): 345-54.

Horng, Jeou-Shyan, Ching-Shu Su, and Siu-Ian Amy So. "Segmenting Food Festival Visitors: Applying the Theory of Planned Behavior and Lifestyle." Journal of Convention \& Event Tourism 14, no. 3 (2013): 193-216.

Hudders, Liselot, Mario Pandelaere, and Patrick Vyncke. "Consumer Meaning Making." International Journal of Market Research 55, no. 3 (2013): 391-412.

Hung, Kuang-peng, Annie Huiling Chen, Norman Peng, Chris Hackley, Rungpaka Amy Tiwsakul, and Chun-lun Chou. "Antecedents of Luxury Brand Purchase Intention." Journal of Product \& Brand Management 20, no. 6 (2011): 457-67. 
Husic, Melika, and Muris Cicic. "Luxury Consumption Factors." Journal of Fashion Marketing and Management 13, no. 2 (2009): 231-45.

Hustvedt, Gwendolyn, and John C. Bernard. "Effects of Social Responsibility Labelling and Brand on Willingness to Pay for Apparel." International Journal of Consumer Studies 34, no. 6 (2010): 619-26.

Jih-Hsin, Tang, and Pam Cheng-Kiang. "The Effect of Interpersonal Influence on Softlifting Intention and Behaviour." Journal of Business Ethics 56, no. 2 (2005): 149-61.

Judith, Schrempf. "Clean Clothes: A Global Movement to End Sweatshops." Society and Business Review 6, no. 1 (2011): 104-06.

Kang, Jiyun, Chuanlan Liu, and Sang-Hoon Kim. "Environmentally Sustainable Textile and Apparel Consumption: The Role of Consumer Knowledge, Perceived Consumer Effectiveness and Perceived Personal Relevance." International Journal of Consumer Studies 37, no. 4 (2013): 442-52.

Keh, Hean Tat, and Yi Xie. "Corporate Reputation and Customer Behavioral Intentions: The Roles of Trust, Identification and Commitment." Industrial Marketing Management 38, no. 7 (2009): 732-42.

Khare, Arpita, Ankita Mishra, Ceeba Parveen, and Rajlaxmi Srivastava. "Influence of Consumers' Susceptibility to Interpersonal Influence, Collective Self-Esteem and Age on Fashion Clothing Involvement: A Study on Indian Consumers." Journal of Targeting, Measurement \& Analysis for Marketing 19, no. 3/4 (2011): 227-42.

Kline, William. "Hume's Theory of Business Ethics Revisited." Journal of Business Ethics 105, no. 2 (2012): 163-74.

Laeequddin, Mohammed, and G. D. Sardana. "What Breaks Trust in Customer Supplier Relationship?". Management Decision 48, no. 3 (2010): 353-65.

Lewick, RJ, and BARBARA BENED1CT Bunker. "Developing and Maintaining Trust in Work Relationships." Trust in Organizations: Frontiers of Theory and Reach (1996): 114-39.

Li-Wen, Lin. "Corporate Social Responsibility in China: Window Dressing or Structural Change?". Berkeley Journal of International Law 28, no. 1 (2010): 64-100.

Lin, Chieh-Peng, Shwu-Chuan Chen, Chou-Kang Chiu, and Wan-Yu Lee. "Understanding Purchase Intention During Product-Harm Crises: Moderating Effects of Perceived Corporate Ability and Corporate Social Responsibility." Journal of Business Ethics 102, no. 3 (2011): 455-71.

Lu, Yaobin, Ling Zhao, and Bin Wang. "From Virtual Community Members to C2c ECommerce Buyers: Trust in Virtual Communities and Its Effect on Consumers' Purchase Intention." Electronic Commerce Research \& Applications 9, no. 4 (2010): 346-60.

Man Kit, Chang. "Predicting Unethical Behavior: A Comparison of the Theory of Reasoned Action and the Theory of Planned Behavior." Journal of Business Ethics 17, no. 16 (1998): 1825-34.

Manning, Mark. "When We Do What We See: The Moderating Role of Social Motivation on the Relation between Subjective Norms and Behavior in the Theory of Planned Behavior." Basic \& Applied Social Psychology 33, no. 4 (2011): 351-64.

McKee, Daryl, Christina S. Simmers, and Jane Licata. "Customer Self-Efficacy and Response to Service." Journal of Service Research 8, no. 3 (2006): 207-20.

Mukhopadhyay, Anirban, and Gita Venkataramani Johar. "Where There Is a Will, Is There a Way? Effects of Lay Theories of Self-Control on Setting and Keeping Resolutions." Journal of Consumer Research 31, no. 4 (2005): 779-86. 
Nguyen, Bang, T. C. Melewar, and Junsong Chen. "A Framework of Brand Likeability: An Exploratory Study of Likeability in Firm-Level Brands." Journal of Strategic Marketing 21, no. 4 (2013): 368-90.

Nica, Elvira. "Marketing Implications of Consumer Behavior." Economics, Management, and Financial Markets, no. 1 (2013): 124-29.

Paul, Chris A. "Managing Integrity Programmes in a Litigious Society." Journal of Pipeline Engineering 7, no. 1 (2008): 39-48.

Pickett, Lela L., Harvey J. Ginsburg, Roque V. Mendez, Deborah E. Lim, Kalah R. Blankenship, Loren E. Foster, Deziree H. Lewis, et al. "Ajzen's Theory of Planned Behavior as It Relates to Eating Disorders and Body Satisfaction." North American Journal of Psychology 14, no. 2 (2012): 339-54.

Powell, Benjamin, and Matt Zwolinski. "The Ethical and Economic Case against Sweatshop Labor: A Critical Assessment." Journal of business ethics 107, no. 4 (2012): 449-72.

Shaw, Deirdre, Edward Shiu, Louise Hassan, Caroline Bekin, and Gillian Hogg. "Intending to Be Ethical: An Examination of Consumer Choice in Sweatshop Avoidance." 2007/01// 2007.

Shaw, Deirdre, and Dominique AC Tomolillo. "Undressing the Ethical Issues in Fashion: A Consumer Perspective." International retail marketing: a case study approach (2004): 141-54.

Shen, Bin, Yulan Wang, Chris KY Lo, and Momoko Shum. "The Impact of Ethical Fashion on Consumer Purchase Behavior." Journal of Fashion Marketing and Management 16, no. 2 (2012): 234-45.

Shukla, Paurav. "The Influence of Value Perceptions on Luxury Purchase Intentions in Developed and Emerging Markets." International Marketing Review 29, no. 6 (2012): 574-96.

Smith, Jeffery. "Rising above Sweatshops: Innovative Approaches to Global Labor Challenges." Journal of Business Ethics 60, no. 1 (2005): 113-14.

Snyder, Jeremy. "Exploitation and Sweatshop Labor: Perspectives and Issues." Business Ethics Quarterly 20, no. 2 (2010): 187-213.

Southey, Gregory. "The Theories of Reasoned Action and Planned Behaviour Applied to Business Decisions: A Selective Annotated Bibliography." Journal of New Business Ideas \& Trends 9, no. 1 (2011): 43-50.

Spector, Paul E. "Locus of Control and Social Influence Susceptibility: Are Externals Normative or Informational Conformers?". Journal of Psychology 115, no. 2 (1983): 199.

Spiggle, Susan, Hang T. Nguyen, and Mary Caravella. "More Than Fit: Brand Extension Authenticity." Journal of Marketing Research (JMR) 49, no. 6 (2012): 967-83.

Sweetin, Vernon H., Lynette L. Knowles, John H. Summey, and Kand S. McQueen. "Willingness-to-Punish the Corporate Brand for Corporate Social Irresponsibility." Journal of Business Research 66, no. 10 (2013): 1822-30.

Vitell, Scott, Megan Keith, and Manisha Mathur. "Antecedents to the Justification of Norm Violating Behavior among Business Practitioners." Journal of Business Ethics 101, no. 1 (2011): 163-73.

Wang, Fang, Zhang Hongxia, Zang Hengjia, and Ming Ouyang. "Purchasing Pirated Software: An Initial Examination of Chinese Consumers." Journal of Consumer Marketing 22, no. 6 (2005): 340-51.

Wolny, Julia, and Claudia Mueller. "Analysis of Fashion Consumers' Motives to Engage in Electronic Word-of-Mouth Communication through Social Media Platforms." Journal of Marketing Management 29, no. 5/6 (2013): 562-83. 